\title{
Prevalence of Plasmodium species in human population of taluka Pano-aqil, Sindh, Pakistan
}

Mehtab Ali Mahar ${ }^{1 *}$, Abdul Manan Sheikh ${ }^{1}$, Nadir Ali Birmani ${ }^{2}$, Safdar Ali Ujjan ${ }^{1}$ and Badar Alam Samejo ${ }^{1}$

1. Department of Zoology, Shah Abdul Latif University, Khairpur-Pakistan

2. Department of Zoology, University of Sindh, Jamshoro-Pakistan

*Corresponding author's email: mehtabmahar87@gmail.com

Citation

Mehtab Ali Mahar, Abdul Manan Sheikh, Nadir Ali Birmani, Safdar Ali Ujjan and Badar Alam Samejo. Malaria burden. Pure and Applied Biology. Vol. 8, Issue 2, pp1420-1424. http://dx.doi.org/10.19045/bspab.2019.80082

Received: 01/01/2019

Revised: 29/04/2019

Accepted: 02/05/2019

Online First: 09/05/2019

\section{Abstract}

The study was conducted to check the prevalence of Plasmodium species in population of Taluka Panoaqil, Sindh, Pakistan during January to December, 2014. The data was collected age, sex and month wise. A total of 2257 samples were collected and out of them only $15 \%$ were positive with malaria. Among positive cases, $80 \%$ were $P$. vivax and $20 \%$ were $P$. falciparum. The month-wise data shows the maximum burden of $P$. vivax $(100 \%)$ was recorded in July and minimum burden was recorded in March (58\%), whereas, the maximum burden of P. falciparum (41.66\%) was recorded in March and minimum load was recorded in September (15.21\%). The age-wise prevalence shows the maximum burden of $P$. vivax $(85.14 \%)$ in over 21 year age group and minimum burden $(77.27 \%)$ in 1-10 and 11-20 year age group, whereas, the maximum burden of $P$. falciparum (22.77\%) in 1-10 and 11-20 year age group and minimum burden $(14.85 \%)$ in over 21 year age group.

Keywords: P. falciparum; P. vivax; Pano-aqil; Sindh; Pakistan

Introduction

Malarial parasites comprising more than 200 species of Plasmodium are known to infect various animal species such reptiles, birds, and mammals. Four Plasmodium species ( $P$. vivax, $P$. falciparum, $P$. malariae, $P$. ovale) are known to cause damage to Human nature [1]. Another species, P. knowlesi found to infect macaque is considered to be zoonotic in human [2]. Mosquito, the vector of Plasmodium in human play very important role in the epidemiology of malaria, west Nile virus and dengue fever etc [3]. WHO reports around 140 million people in Pakistan are at risk of malaria and among them about $18 \%$ live at high risk [4]. Report indicates the work has been done on the prevalence of Plasmodium species in human population in Pakistan [5-8], but none of the report is available from the study area. It was therefore, proposed to carry out the survey on the prevalence of Plasmodium species in human population of taluka Panoaqil, Sindh, Pakistan.

\section{Materials and methods}

From January to December, 2014, the present study was conducted in human population of taluka Pano-aqil, Sindh, Pakistan. The data was collected from government hospital Pano-aqil and malaria centers in Taluka Pano-aqil. The data collection method was followed of Yasinzai 
and Kakarsulemankhel [9, 10]. The data was analyzed month-wise, age-wise and sexwise. Three age groups 1-10 years, 11-20 years and 21 and/or above years were

\section{Results}

Suspected malarial cases were studied to separate the $P$. vivax and $P$. falciparum. Among these positive cases, $80 \%$ cases were infected with $P$. vivax and $20 \%$ cases were infected with $P$. falciparum (Table 1).

Maximum load of $P$. vivax was recorded in the month of July and minimum in month of March, whereas, maximum load of $P$. falciparum was recorded in the month of March and minimum in month of September (Figure 1). prepared. Data was statistically analyzed to know the complete prevalence of $P$. vivax and $P$. falciparum within the study rea.

Moreover, as results show that $P$. vivax was noted greater in 21-above age group, whereas, lesser in 1-10 and 10-20 year age group. The prevalence of $P$. vivax was observed higher in 1-10 and 11-20 year age group and lesser in 21-above years age group (Table $2 \&$ Figure 2). So far the gender-wise prevalence is concerned, maximum load of Plasmodium vivax was observed in males and females but the ratio of $P$. falciparum was noted lowest in males and females in present locality (Table $3 \&$ Figure 3).

Table 1. Month-wise prevalence of Plasmodium species in taluka Pano-aqil

\begin{tabular}{|c|c|c|c|c|}
\hline Month & Suspected cases & Positive cases \% & P.falciparum \% & P. vivax \% \\
\hline January & 315 & 23.80 & 17.33 & 82.66 \\
\hline February & 155 & 9.67 & 20 & 80 \\
\hline March & 187 & 6.41 & 41.66 & 58.33 \\
\hline April & 177 & 5.08 & 22.22 & 77.77 \\
\hline May & 163 & 15.95 & 30.76 & 69.23 \\
\hline June & 161 & 9.93 & 31.25 & 68.75 \\
\hline July & 90 & 3.33 & 00 & 100 \\
\hline August & 134 & 27.61 & 21.62 & 78.37 \\
\hline September & 236 & 19.49 & 15.21 & 84.78 \\
\hline October & 153 & 14.37 & 27.27 & 72.72 \\
\hline November & 252 & 13.88 & 22.85 & 77.14 \\
\hline December & 234 & 20.08 & 10.63 & 89.36 \\
\hline Total & $\mathbf{2 2 5 7}$ & $\mathbf{1 5 \%}$ & $\mathbf{2 0 \%}$ & $\mathbf{8 0 \%}$ \\
\hline
\end{tabular}

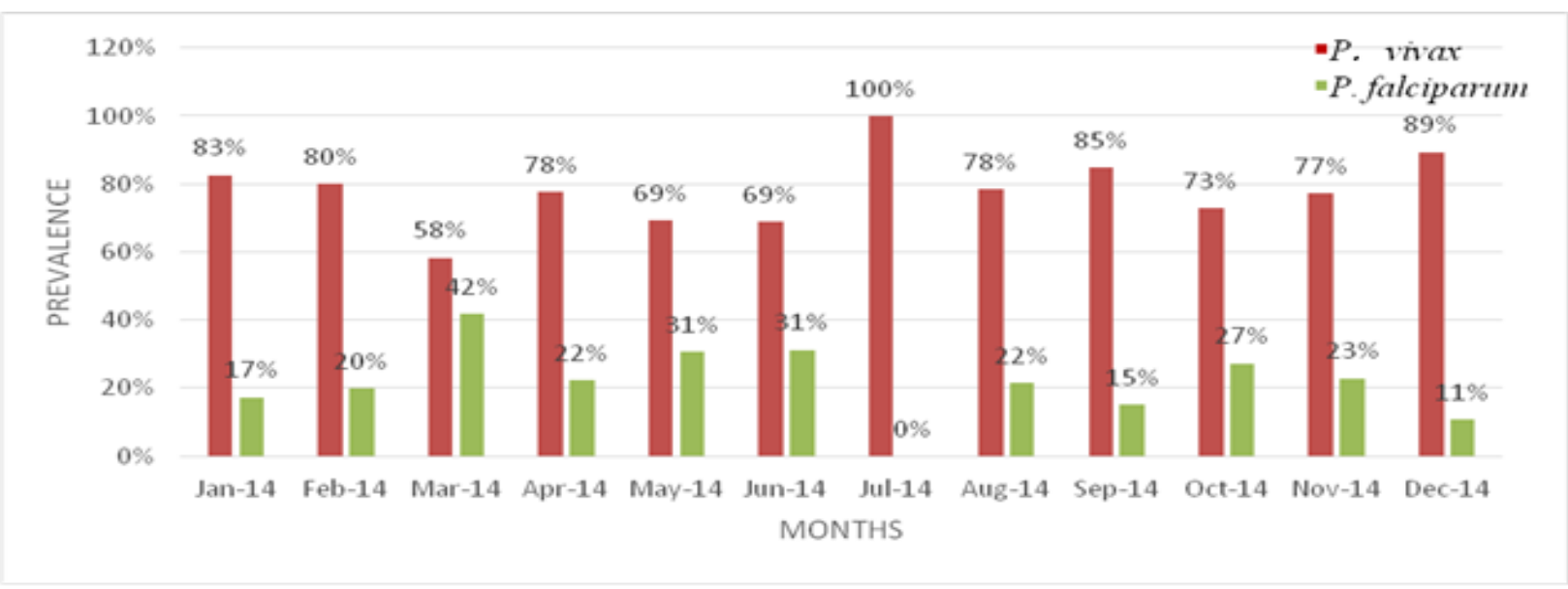

Figure 1. Month-wise prevalence of Plasmodium species in taluka Pano-aqil 
Table 2. Age-wise prevalence of Plasmodium species in taluka Pano-aqil

\begin{tabular}{|c|c|c|c|}
\hline Age & P. vivax \% & P. falciparum \% & Total Positive cases \\
\hline 1-10 years & $\mathbf{7 7 . 2 7}$ & $\mathbf{2 2 . 7 2}$ & 110 \\
\hline $\mathbf{1 1 - 2 0}$ years & $\mathbf{7 7 . 2 7}$ & $\mathbf{2 2 . 7 2}$ & $\mathbf{1 3 2}$ \\
\hline 21 and above years & $\mathbf{8 5 . 1 4}$ & $\mathbf{1 4 . 8 5}$ & $\mathbf{1 0 1}$ \\
\hline Total & $79.59 \%$ & $20.40 \%$ & 343 \\
\hline
\end{tabular}

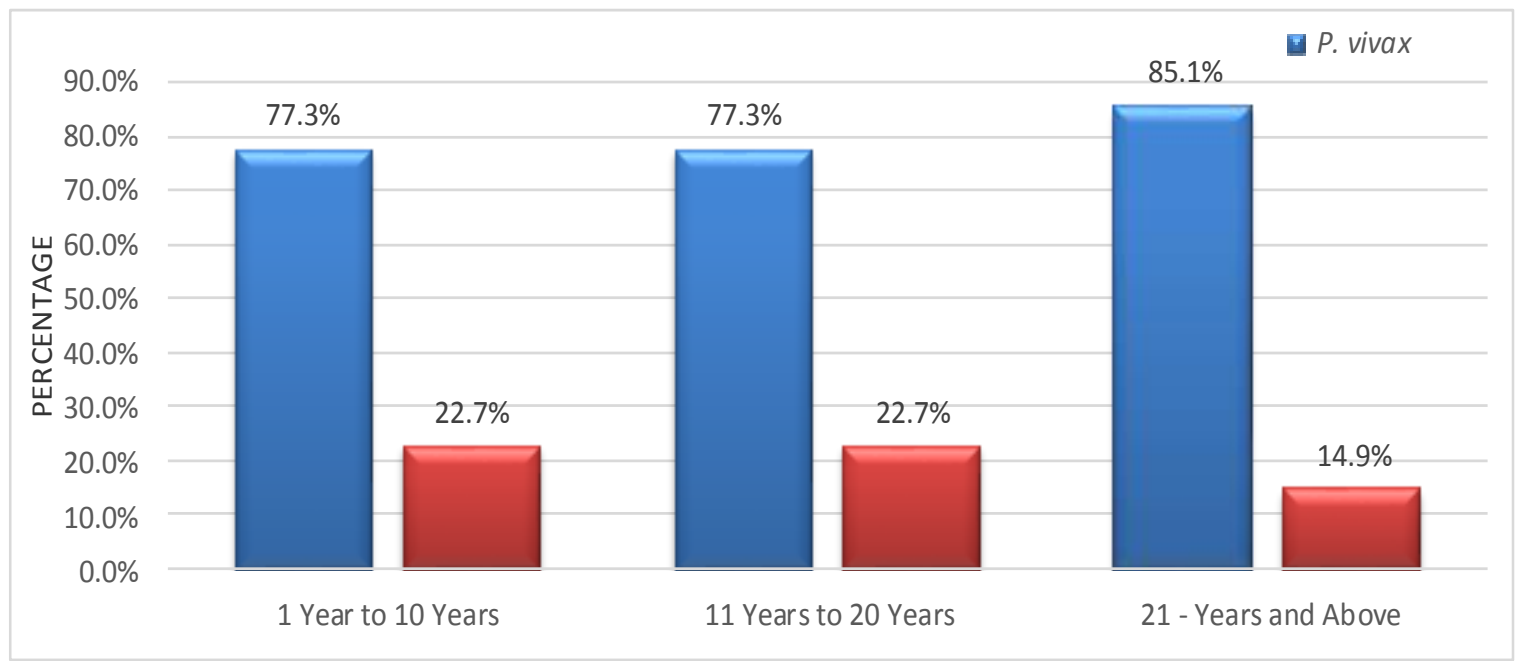

Figure 2. Age-wise prevalence of Plasmodium species in taluka Pano-aqil

Table 3. Sex-wise prevalence of Plasmodium species in taluka Pano-aqil

\begin{tabular}{|c|c|c|c|c|c|c|}
\hline $\begin{array}{c}\text { Taluk } \\
\text { a }\end{array}$ & $\begin{array}{c}\text { Positive } \\
\text { Cases } \\
\text { (Male) }\end{array}$ & $\begin{array}{c}\text { Percentage } \\
\text { of } \boldsymbol{P} \text {. vivax } \\
\text { (Male) }\end{array}$ & $\begin{array}{c}\text { Percentage of } \\
\boldsymbol{P} \text {. falciparum } \\
\text { (Male) }\end{array}$ & $\begin{array}{c}\text { Positive } \\
\text { Cases } \\
\text { (Female) }\end{array}$ & $\begin{array}{c}\text { Percentage of } \\
\boldsymbol{P} \text {. vivax } \\
\text { (Female) }\end{array}$ & $\begin{array}{c}\text { Percentage of } \\
\text { P. falciparum } \\
\text { (Female) }\end{array}$ \\
\hline $\begin{array}{c}\text { Pano- } \\
\text { aqil }\end{array}$ & $\mathbf{2 3 3}$ & $77.25 \%$ & $22.74 \%$ & $\mathbf{1 1 0}$ & $84.54 \%$ & $15.45 \%$ \\
\hline
\end{tabular}

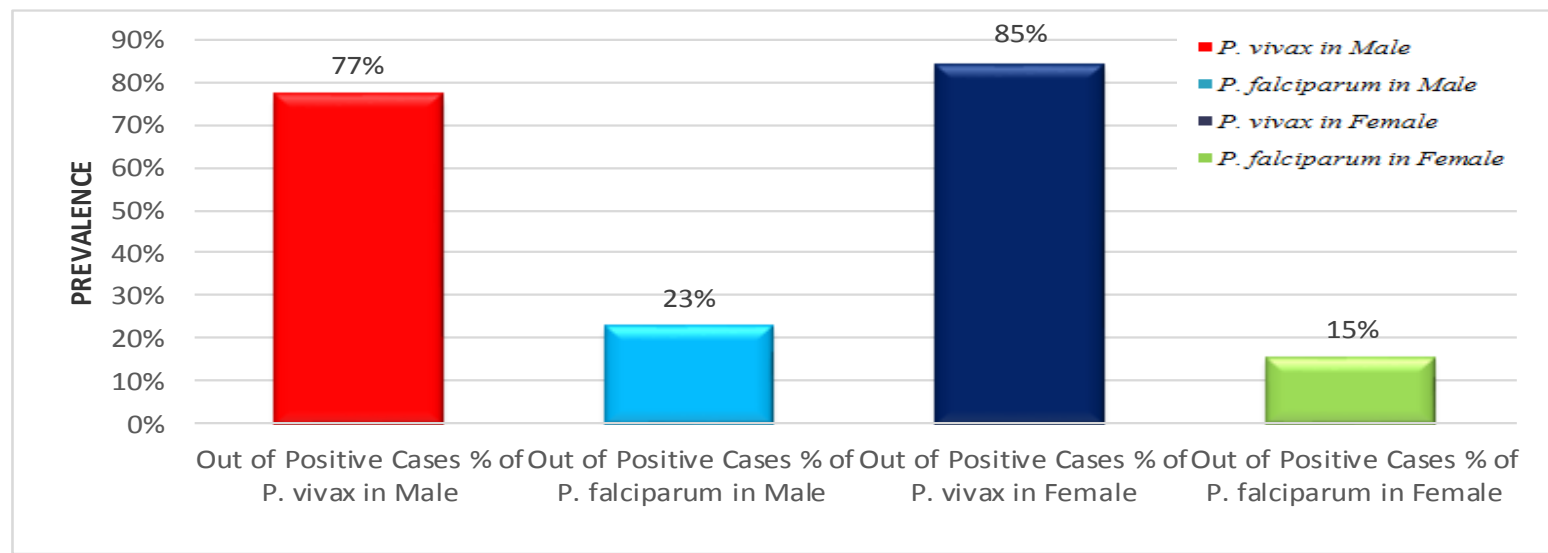

Figure 3. Sex-wise prevalence of Plasmodium species in taluka Pano-aqil 


\section{Discussion}

According to the report, more than three million human beings live under malarial threat in 24 affected countries [11]. Malaria disease transmits to people when an infective female Anopheles mosquitoes Malaria vector - bites. They often bite during dusk and dawn [12]. In present study the total 2257 suspected cases were studied and out of these only $15 \%$ found to be positive cases. The $P$. vivax was recorded with the highest prevalence $80 \%$ and $P$. falciparum was recorded with $20 \%$. The other previous reports of [13-20] conducted in Pakistan also support the highest prevalence of $P$. vivax than $P$. falciparum. In present study, the $P$. vivax was $100 \%$ in the month of July, whereas, $58 \%$ in the month of March. P. falciparum was observed $42 \%$ in the month of March, whereas, not seen in the month of July. In previous reports $[9,10$, 21, 22], the month-wise prevalence of $P$. vivax and $P$. falciparum varies due to geographical variation, habitat differences and climatic conditions. In present study, the $P$. vivax was $85.14 \%$ in 21 and above year age group and $77.27 \%$ in $1-10$ and $11-20$ year age group, while $P$. falciparum was $22.72 \%$ in $1-10$ and $11-20$ year age group and $14.85 \%$ in 21 and above year age group. In previous reports $[9,10,21,22]$ the agewise prevalence varies due to geographical variation, habitat differences and climatic conditions. In present study, the $P$. vivax was recorded highest in both male $(77.25 \%)$ and female (84.54\%), while $P$. falciparum was recorded lowest in both male $(22.74 \%)$ and female $(15.45 \%)$.

\section{Conclusion}

The present study concludes that the burden of $P$. vivax is higher than $P$. falciparum in taluka Pano-aqil. The burden of $P$. vivax is higher in the month of July, whereas, the burden of $P$. falciparum is higher in the month of March. No differential results were found sex-wise. The burden of $P$. vivax is higher in 21 and above year age group, whereas, the burden of $P$. falciparum is higher in 1-10 and 11-20 year age group.

\section{Authors' contributions}

Conceived and designed the experiments: MA Mahar, Performed the experiments: MA Mahar, Analyzed the data: NA Birmani, SA Ujjan \& BA Samejo, Contributed reagents/ materials/ analysis tools: MA Mahar \& AM Sheikh, Wrote the paper: Mahar MA \& SA Ujjan

\section{Acknowledgement}

I am greatly indebted to Professor Dr. Aftab Ahmed Soomro, Principal Ghulam Muhammad Mahar Medical College Sukkur. Without his kind and timely support, it would have been nearly impossible for me to collect data needed for my Research Work from different Hospitals and Basic Health Units in Pano-aqil Taluka, District Sukkur.

\section{Reference}

1. Kho WG (2007). Reemergence of malaria in Korea. $J$ Korean Med Assoc 50(11): 959-966.

2. Chin W, Contacos PG, Collins WE, Jeter MH, \& Alpert E (1968). Experimental mosquito-transmission of Plasmodium knowlesi to man and monkey. Am J Trop Med Hyg 17(3): 355-358.

3. Rueda LM (2008). Global diversity of mosquitoes (Insecta: Diptera: Culicidae) in fresh water. Hydrobiol 595: 477-487.

4. WHO (2009). World malaria report Geneva.

5. Covell G (1931). The present state of the knowledge regarding the transmission of malaria by different species of Anopheline mosquitoes. Rec Malaria Surv India 2: 1-48.

6. Memon IA (1997). Dominant malaria parasite species in hospitalized children in Nawab Shah and chloroquine resistance. Pakistan J. med. Sci., 13: 245-248. 
7. Afridi AK, Khan J, \& Khan GS (1998). The incidence of malaria in an urban slum of Peshawar. J Med Sci 8: 102105.

8. Bhalli MA, \& Samiullah (2001). Falciparum malaria -a review of 120 cases. J Coll Phys Surg Pak 11: 300303.

9. Yasinzai MI \& Kakarsulemankhel JK (2008). Prevalence of Human Malaria Infection in Pakistan: District Dera Murad Jamali. Pak J Sci 60: 3-4.

10. Yasinzai MI \& Kakarsulemankhel JK (2012). Prevalence of Human Malaria Infection in Bordering Areas of Baluchistan with Sindh Province: District Jaffarabad. J Postgraduate Med Ins 26 (03): 277-282.

11. WHO/UNICEF (2005). World malaria report Geneva.

12. White GB (1974). Anopheles gambiae Complex and disease transmission in Africa. Trans R Soc Trop Med Hyg 68: 278-301.

13. Mohammad N \& Hussain A (2003). Prevalence of malaria in general population of district Buner. J Pak Med Ins 17(1): 75-80.

14. Sheikh AS, Sheikh AA, Sheikh NS \& Paracha SM (2005). Endemicity of malaria in Quetta. Pak J Med Res 44(1): 7.

15. Idris MJ, Sarwar \& Fareed J (2007). Patreen of malaria infection diagnosed at Ayub Teaching Hospital Abbottabad. J Ayub Med Coll 19: 35-36.
16. Yasinzai MI \& Kakarsulemankhel JK (2007a). Incidence of malaria infection in Pak-Afghan border area of Pakistan: District Qilla Abdullah-Chaman. Hamdard Med 50: 62-66.

17. Yasinzai MI \& Kakarsulemankhel JK (2008b). Incidence of human malaria infection in northern hilly region of Balochistan adjoining with NWFP, Pakistan: District Zhob. Pak J Biol Sci 1620-1624.

18. Murtaza G, Memon IA, Memon AR, Lal MN \& Kallar NA (2009). Malaria morbidity in Sindh and the Plasmodium Species distribution. Pak J Med Sci 25(4): 646-649.

19. Soomro FR, Pathan GM, Bajaj D \& Kakar JK (2010a). Malarial parasites species; Jacobabad District Sindh, Pakistan. Professional Med J 17(3): 440-443.

20. Asif N (2011). Malaria in Shorkot garrison- a four-year experience report. Pak J Path 22(2): 58-64.

21. Khan HU, Khattak AM, Khan MH, Mahsud IU \& Humayun S (2013). A study of prevalence of malaria in adult population of DI Khan, Pak Biomedica 22: 99-104.

22. Jan AH \& Kiani TA (2001). Haematozoan parasites in Kashmiri refugees. Pak J Med Res 40: 10-12.

23. Yasinzai MI \& Kakarsulemankhel JK (2009). Incidence of human malaria infection in Central Baluchistan, Pakistan: District Bolan. Biologia 55(1,2): 43-50. 